\title{
Investigating the Reasons of the Lack of Consideration to Averroes's Philosophy in Iran Focusing the Most Important Ideas of Some Scholars
}

\author{
Ghasem Rezaee \\ PhD student of Philosophy, University of Isfahan \\ Email:G.rezaee@yahoo.com
}

Mohammad Javad Safian

Associate professor of the department of philosophy, university of Isfahan

Email:javadsafian777@gmail.com

\section{Doi:10.5901/mjss.2014.v5n9p535}

\begin{abstract}
Averroes, as one of the greatest philosophers following Aristotle who knows himself to be commitment to reason, has been never considered in Iran. This is done while Avicenna, his the other Aristotelian philosopher, has always been considered by Iranian scholars and his philosophy is considered as the only pure and genuine reading of Aristotle's philosophy. The reason of the lack of considering Averroes' thoughts in Iran are so profound and indicate his different approach to two concepts of religion and philosophy. Some scholars consider the nature of Averroes's thought to have significant differences with Avicenna's. Regarding this issue from their perspectives largely indicates the separation of ideas and thoughts between the east and west of Islamic world, while according to some others, such differences are meaningless and nobody can speak of any separation between the religious culture of the west and east of Islamic world. The claim of the present article is that the different ideas and heterogeneity of views between these two great Islamic philosophers enjoy more rational and historical support and legitimacy.
\end{abstract}

Keywords: Iran, eastern philosophy, Averroes's philosophy, Avicenna's philosophy.

\section{Introduction}

Abu-Al-Valid Muhammad Ibn Ahmad IbnRushd, better known in Western as Averroes, was born in $520 \mathrm{AH}$ coincides with 1126 AD in Córdoba, the capital of Andalusia exactly 15 years after Ghazali's death occurred in 505 AH. His ancestors were well known in jurisprudence, politics and judiciary. Averroes' great ancestor, Abu-Al-Valid was the judge of Córdoba and was considered one of the great jurisprudents of Maleki religion. Averroes is the master of medicine, philosophy, theology, jurisprudence and poetry and has some writings in these fields. His knowledge on medicine and philosophy distinguish him more from his contemporaries and his philosophical dimension had the most influence in the periods after him.

This great philosopher's life and the way he entered governmental and political affairs and also his relationship with politicians are recorded in historical books and there is no need to repeat them here. What is obvious is that he had some relations with the court and the government which in different historical sections resulted in his dissatisfaction and hatred; at last in $595 \mathrm{AH}$, he returned home from an exile and a little later died of disease (Adamson, 2005).

Philosophical works of Averroes is so various and numerous that can be comparable with the works of other great eastern philosophers. Two significant features of him opposing to Farabi and Avicenna are his effort to explain and interpret Aristotle's main texts and effort to resolve the challenge of the relationship between philosophy and religion. Averroes, in addition to writing interpretations on Aristotle's works, tried to present independent works as well. These works he mainly wrote to criticize and reject topologists and philosophers particularly Farabi and Avicenna to some extent indicate the distance of these two philosophers from Aristotle.

His works can be divided into three categories: interpretations which he wrote on Aristotle's philosophy. His criticisms of Farabi and Avicenna in line with supporting the genuine philosophy of Aristotle which in Averroes' view, these two philosophers either poisoned or misunderstood. Finally demonstrating the principles of harmony or disharmony between philosophy and religion, which can be considered as one of the most important part of philosophical discussions. He knows the confirmation of this issue dependent on the fact that humans understand and interpret well both fields. 
Averroes as one of the most influential thinkers of medieval Christianity, had a great proportion in resolution of the issue of relationship between philosophy and religion (Fakhri, 1993). However, obviously, he cannot find a path through the east and was not welcome in the eastern lands. Factors and reasons of pessimism should be sought in the content of Averroes's thoughts and the kind of his approach to basic issues of ontology. The obvious point here is that Averroes is still indiscoverable for eastern thoughts. Therefore, some consider him as the end of philosophical thought in Islamic societies (Renan, 1957). This statement is apparently untrue, but in a deeply investigated, Averroes is the end of philosophy in Islamic societies. What continues after Ghazali's attacks in eastern societies is not more than mystical and religious philosophy. Concerning this issue Bertrand Russell argues that:

\begin{abstract}
"The importance of Averroes in Christian philosophy is more than Islamic philosophy. In Islamic philosophy, he is no more than astalemate; however, in Cristian philosophy, he is considered the origin. Michael Scott translated his works into Latin and since Averroes had written those works in the second half of the twelfth century, this issue is stupendous. He had influences among not only scholastic philosophers, but also liberal informal thinkers who denied the existence of the soul and were called Averroeseans. Among professional philosophers, one can name Franciscan monks and then Parisian academics (Russell, 1994: 598).
\end{abstract}

However, the issue whether Averroes's thoughts is the opposite of eastern philosophers or not, is the issue that this article is to find. What is clear is that the journey of philosophy in the east of Islamic world welcomed mysticism and theosophy and finally resulted in accompanying philosophy, theology, mysticism, and the Quran according to the claim of followers of Transcendent Theosophy and the pain of discrepancies ended (Ashtiani, 1999: 26), while Averroes's thought is located in the opposite point of mentioned approach and is known as Rationalism. Averroes is the only philosopher who in addition to Islam, is loyal to teachings, principles and method Peripatetic philosophy disciplined by Aristotle. He knew Farabi and Avicenna as theologians; therefore, he made attempts to revive Aristotle's genuine thought in the framework of religious teachings and proposed a different ideology. He also tried to consider Islamic scholars intentions in addition to being loyal to Aristotle.

These are discussions which in the view of some scholars, make him the greatest philosopher in the west of Islamic world. Although it may be that this view contains a kind of exaggeration, may scholars know him as an exemplar of a religious philosopher in Islamic culture and civilization (Leman, 2004: 165). His interpretation of Aristotle is the foundation of a kind of philosophical tradition in the West, which the followers of this school are called Latinate Averroesean. But this Islamic thinker has not been known in Iran and it seems that regarding his thoughts, he will not be considered as important since he think differently, the kind of Averroes's thought is from a different nature. What primarily is important for Averroes is absolute devotion to Reason whose only symbol is Aristotle. He places the role of religion besides Reason and in the second status. Furthermore, Averroes does not pursue the sum of religion with philosophy. The title of his only work in this regard indicates ending a long-established conflict. Therefore, he wants to determine closely thought fields, not merging one into another.

Nowadays, a lot of Arabic Islamic countries ask the solution if being faithfulness in the new world from Averroes and respect his resolution greatly (Atef-Al-Araghi, 2002: 236 and Abed-Al-Jaberi, 1994: 136); however, some believe that this tendency to reach a secularist world (Nasr, 2006: 309).

However,our lack of information regarding this powerful tendency in Islamic world is not defendable and if our contemporary Arab attempted this issue and was interested in it, it indicates that Averroes considers a different kind of thought and view. A thought which is their guide to attain a modern world and maintain legacies and traditional and religious tradition. If they consider Averroes, this issue is not odd. Averroes's thought contains elements which is easily matched with the modern world. Some of these features are as follows:

\title{
2. Characteristics of Averroes's Thought
}

1. Averroes was humble and critical and was careful in his works and ideas. In his multiple positions if the book of "Al-Tahafat Al-Tahafat" believes that humans' reasons are incomplete and accepts his errors (Averroes, 1999: 265; Vol. 1). DeBeur writes that Averroes thanked his enemies for the uses they had offered him and this is his good temperament (DeBeur, 1983; 210).

2. Averroes speaks of human rights and particularly rights of women; he believes that during history, women are suppressed and oppressors prevent women from attaining a proper human status in science, understanding and practice (ibid).

Debore writes that in Averroes's view, misery and poverty his time are related to this fact that men grasp women for his own sake and they keep them as plants and pets only for fleeting and unstable enjoying, 
instead that women are allowed to participate in material wealth and intellectual outcomes and keeping them (ibid, 211).

3. Averroes looks at history and the past unbiasedly (Davari, 2010: 326).

4. Averroes rejects asceticism and isolation and does not take art and knowledge as useful. He emphasizes that each person is required to participate in happiness and improvement of his society. He considers topologists as his enemies mainly because they are the enemies of modernism and reformation and emissionof culture and severely criticizes them (De Beur, ibid: 210).

If one compare what have been said with the total sayings of eastern philosophers, he can rarely pursue these issues in the thoughts of eastern philosophers. In some cases, the approach of some philosophers like MullaSadra's regarding social concepts of women is so absurd that it is not comparable with Averroes's. As mentioned, because of the existence of such thoughts in Averroes's works which some know the peak of Islamic philosophy (Leman, ibid) and some believe that he does not believe in religion (Davidson, 1992: pp256) and what he states about religious teachings is only for agreement of common beliefs (Harold-1996-pp77), and one can pursues his beliefs among his interpretations (Al-helou, 1960: 256). In other words, according to this people, Averroes hides himself under the disguise of Aristotle. However, on the other side, there are a group of righteous people who rise against religion and merely are to state "quotation" and this does not mean his personal belief (Jaberi, 1998: 17).

Durant writes:

\begin{abstract}
"About 1240, following Averroes's ideas was common among all educated non-clergies. Thousands of people accepted his beliefs and believed in following him who claimed that natural law controls world without any interference of God. The world is equal to God in terms of eternity, only an immortal soul or intellectual active power is available in the world, which an individual's soul refers to the unstable form or shape and finally heaven and hell are myths which are fabricated for deceiving or fearing people to obey standards of chastity (Durant, 1986, vol. 4: 1289).
\end{abstract}

Regarding what mentioned, undoubtedly, Averroes has not any status in Iran. What are the implications of the difference between east and west? Why is Avicenna considered the only distinguished philosopher in the east and mainly in Iran, but his rival encounters unwillingness in the west of Islamic world? Where the reasons of this willingness and wretchedness should be pursued? Is this lack of attention because of a mere kind of misinterpretation or it has more profound layers?

\title{
3. Ideas of Some of Scholars Regarding the Lack of Attention to Averroes's Thought in Iran
}

Most of Arab, Persian and sometimes orientalist historians and scholars of world believe that the flow of philosophical thought in two geographies of east and west of Islamic world, each journeyed a certain path and achieved different conclusions. Amidst, some believe that the philosophical fortune and nature of Islamic world are totally different and this difference is primarily due to the difference in ideas and preoccupations of philosophers and scholars of these two lands of Islamic world.

Eastern philosophers primarily attempted to establish a system which was interested in religion and religious principles to organize faithful beliefs and religious beliefs and to interpret and explain religious principles and beliefs and sometimes to defend them against opponents focusing materials which Greek philosophy presents for them. In most of the issues, in this system the theological and religious issues were followed in such a way that its path ended to mystics and Sufism. Reason, in the view of these scholars, is not a free reason. Reason journeys to achieve those objectives that religion is revealed in line with. Therefore, philosophy should move based on religious principles and standards; otherwise, this reason will be considered as a factor to stand against religion and faithfulness and will be rejected from the faithful's society. In case of opposition to the mentioned idea, undoubtedly religious reason in addition to having at least a religious and national concern, tries to not deviate from the path of religion. The peak of this theory can be seen in MullaSadra'sTranscendent Theosophy considered as the peak of mysticism and philosophy of the East. However, MullaSadra hates the philosophy whose principles are against the holy religion (Al-Shirazi, 1981: Vo. 8: 396) and the novice of this great school, Ashtiani introduces Transcendent Theosophy as a period of rational theology in Shiite school (Ashtiani, 1999:14). Averroes considers another path. In this line, two basic theories are proposed by scholars:

1. Dissonance and difference Theory

2. Homology and commonalityTheory

Dr. Mohammad Abed-Al-Jaberi (2008), Professor Henry Corbin (1994) and Dr.RezaDavari (2010) believe that among Islamic philosophy in the east and west of Islamic world, and differences and discrepancies are present particularly when 
these discrepancies between Avicenna in the east and Averroes in the west are more significant. Among those who believe these discrepancies, the ideas of Dr. EbrahimiDinani can be mentioned (EbrahimiDinani, 2000: 218):

\section{Dr. Ebrahimi Dinani}

Dr.GholamHosseinEbrahimiDinani, a distinguished professor of Islamic philosophy in the University of Tehran considering the fact that Averroes's philosophy has not been appropriately and comprehensively paid attention to (EbrihimiDinani, 2005: introduction) believes that the distance between east and west is a geographical distance and this distance cannot produce any gap in philosophy (ibid: 213). After a long introduction, he concludes that

"Considering that Islamic philosophy is regarded as the principles of Islamic culture and civilization, we have to accept the fact that in this philosophy there is no geographical distance and dichotomy because culture and civilization are identical which do not accept any discrepancies (ibid: 218). Emphasizing serious and significant discrepancies of these two peripatetic philosopher, he does not consider it as a reason for basic discrepancies of philosophy in the west and east of Islamic world (ibid: 223).

EbrahimiDinani in other different positions refers to these discrepancies. He writes regarding these discrepancies:

"The intellectual position of Averroes toward these two great philosophers, i.e. Abu Nasr Farabi and Avicenna indicates that among Islamic thinkers there is a kind of misunderstanding instead of understanding and familiarity. These misunderstanding and unfamiliarity among western and eastern Islamic thinkers are more significant" (Dinani, 2005: 168). He surprisingly considers the reason of this unfamiliarity as the long geographical distance and in this intellectual alienation, he takes the distance dimension as important (ibid, 169).

Now, the main question is that if the dimension of geographical distance and the lack of information from Averroes's works are the reasons of the alienation between these two philosophers, why in the present time, i.e. the age of information and statistics, the ideas of Averroes are not welcome? On the other hand, why is another fellow countryman of Averroes, Mohiyeddinlbn Al-Arabi more welcome and he is significant in philosophy and mysticism of the east? While geographically, Ib Al-Arabi belongs to that domain. In addition to what mention, this Dinani's statement that culture and civilization enjoys a common approach, is among his unapproved presumptions. Therefore, factors of the lack of information of the most important Islamic philosopher apparently is deeper that what Dinani states. The peak of this lack of information is described by Corbin:

"So far, I only find a clue of Averroes in AbdolrrazaghLahiji, one of the most famous novices of Sadra, without I be able to determine the trace of this clue, indeed, by conditioning that he himself or the writer who distorted his famous name, recorded Ibn Rush as Ibn Rashid" (Corbin, 1990: 111).

In general, it seems that Dinani's idea does not enjoy the justified scientific and historical supports and cannot be considered as one of the reasons of lack of willingness to Averroes's ideas in the west part of Islamic world. Therefore, it can be said that the commonality and homology theory of two approaches in the west and the east of Islamic word to Aristotle's thoughts are lacking the logical and historical legitimacy or at least the reasons to confirm it are not enough.

\section{Dr. Reza Davari}

Dr. Davari, a distinguished professor of the University of Tehran, believes in the difference between western and eastern thoughts in Islamic world. He considers Averroes as an event in Islamic world who by returning to Aristotle's thoughts, is to present a new approach of a reason which was less similar to Aristotelian reason and more to the reason which 200years later entered the circle of philosophy. The reason in which neither philosophy become religious nor religion can be philosophical (Davari, 2010: 21). According to Davari, Averroes entered philosophy into a new land and method, in such a way that the Way back was blocked; therefore, what happened in the west did not entered the east and philosophers remained unaware of it. Therefore, according to him, the nature of Averroes' thought was such that it was approaching to the West and Renaissance's thoughts. This thought was never considered welcome by the easterners and those living in the Medieval. The base of this thought was fundamentally opposing to the medieval scholars.

He continues that "the reason of westerners' attention to Averroes was not without objective because the reason for Averroes in comparison with the reason for philosophers of Islamic world is closer to the reason of modern world and modernism. In other word, the reason for Averroes is not so far from the reason of the modern world and has some proximities with it" (Davari, 2002). He continues that "in the opposite side, the philosophy begun by Farabi was in line with religion and philosophy. This is a fine historical point which in the flourishing era in Iran, philosophers after Ghazali, instead of responding to Ghazali's attacks, tried to show that Ghazali's claims were not justifiable and were mainly the results of misinterpretation" (ibid). 
According to Davari, if Averroes responded Ghazali is due to the fact that he was to defend the philosophy which were not related to religion. Davari believes that the communicative understanding that Averroes drew between religion and philosophy is so difficult that the results of his ideas have been the theory of dichotomous truth in medieval. Responding those who claimed that this statement is true not only about Averroes but also his followers, he writes that:

\begin{abstract}
"If Averroes's works were not interpretable, how his followers found him and how they attributed him as their master?" (ibid). He believes that the history of philosophy started from Socrates joint thedevelopment of philosophy in Europe. 1: through the influence of Farabi and Avicenna on medieval. 2: through Averroes who started to return to Greece as one of the forerunners of renaissance. In fact, Averroeans were the first group who proposed the plan of return to Greece. Therefore, Averroes linked the de-Avicennaized Islamic philosophy to the path of European philosophy and instead of being involved in reinforcing the medieval philosophy, like the case of Farabi and Avicenna, he was effective in the collapse of it and preparing the grounds for renaissance. Therefore, Averroes participated actively in the plan of to make mundane the philosophy which Socrates started it with the sentence "I brought the philosophy to earth". However, Iranian philosophers stepped into another way and reached another destiny (Hemo, 2010: 23).
\end{abstract}

This distinguished professor places the philosophies of Averroes and Avicenna in two different poles of earth and heaven and believes that the philosophy which Plato and Aristotle presented had two different potentialities; one was that it would become mundane and in its ground new science and technology and politics and economics and modern system occur and grow and the other potentiality was that the possibility of remaining heaven signs and tendency to return to heaven should be available. In Islamic world, the philosophy of Averroes joined the first path, but the philosophy in Iran chose the second path which was a difficult one and travelled it with difficulty. Accordingly, it is clear that with the philosophy whose end means achieving completeness in the sense that it achieves survival after death and on the other hand, the realm of people's lives and their world structure is not so important, the science of seizing the advanced world and technology and politics can be established and improved (ibid: 25).

Separating reason for Averroes which tends towards travelling in the earth and may be effective and reason for Avicenna which tends toward the heaven and it is alien and lingered, Davari states that:"Philosophy tends toward the heaven if it cannot find a suitable in public life" (ibid: 29).

Therefore, the easterly view of Islamic philosophy does not contain a significant result because in this view the law pursues the public life in the religion which comes down from the heaven. Therefore, Islamic philosophy, by submitting the principles of public politics to religion, considered the problem of compromising among religion, philosophy and politics and the problem of making philosophy mundane lose its severity. Accordingly, philosophers basically do not consider this problem to be important and do not pay attention to it (ibid: 30). Davari clearly believes that Averroes's philosophy is a kind of deviation of Islamic philosophy and return to the pure and genuine philosophy of Aristotle; therefore, he noticed the movement of philosophy toward the new world (ibid: 42).

He attentively considers the historical development of Islamic philosophy which he has nurtured or could nurture. In his view, when we think of the development of Islamic philosophy, we can find two reverse streams in it. The first is the philosophy which Farabi begun and Avicenna and Suhrawardi ended it. This philosophy listened to the west and looked at the east. In better words, it has two easterly and westerly sides. However, there is another philosophy which although at first it has a religious theological view, gradually speaks of the separation between religion and philosophy and east and west and then moves toward the west so that it will be solved in the new philosophy. But the other path which has continued to the present century suffers from western alienation. Therefore, the development of philosophy in the western part of Islamic world was such that it kept away religion and philosophy and finally separated them (ibid: 67).

Davari presents other interesting issues which in general accepts his words in response to the lack of willingness of eastern thinkers to Averroes's philosophy in addition to the mentioned insights.

"In my view, Averroes looked at Europe and could be the connecting chain between Islamic philosophy and European one. Even the unity of the history of philosophy necessitates that if philosophy has moved to some extent towards theology, it should return to its origin. Averroes brought the theological tendency to the pure philosophy and noticed medieval people that they should return from theology to philosophy and this call was one of the results which ended to renaissance".

He adds: maybe the ideas of those who consider Averroes as the last philosopher of Islamic world are justifiable in this way that Islamic world is a combination of philosophy, theology and mysticism after Averroes (ibid, 321).

Being surprised that the issue of unwillingness to Averroes in the east of islamic world is more complicated than unwillingness of orientalists and historians of philosophy to MullaSadra and Suhrawardi, Dr. Davari believes that this unwillingness is no justifiable because in his view, the thinkers who belong to the same world and their issues are common, cannot be reckless to the works of each other (ibid: 322 ). 
Accordingly, the final idea of Dr. Davari is that "Averroes's philosophy cannot be placed in the dominant discourse of Iranian philosophy and consequently they did not consider his writings as thinking in the philosophy" (ibid).

He considers the theory of geographical distance and geographical longitude of West and Eastas a reason for the lack of willingness to Averroes's ideas to be superficial, and he believes that those such as Mian Mohammad Sharif in the history of philosophy (1362: 53, vol. 3) and Dr. Dinani who presents this theory, does not sate a precise theory.

For this reason, he takes Averroes as the teacher of renaissance and the guider of new civilization in the west and in this issue he did not hesitate for a moment. He considered this issue as important and did not take it as justifiable. In his view, Averroes by deconstructing Islamic philosophy and separating Aristotelian ideas from theological and semitheological ideas, created grounds in order that those who wanted to exit from medieval Christianity resorted to Aristotle because renaissance was the return to Greece; therefore, why the attempt to return to the real Aristotle cannot be taken as moving in line with renaissance (Helo, 2010: 326).

\title{
6. Ideas of Dr. Mohammad Abed Al-Jaberi
}

Dr. Abed Al-Jaberi, former professor at the University of Rabat is among the thinkers who believe that philosophy in the west of Islamic world is not only the natural continuance of philosophy in the east of Islamic world, but also basically this philosophy is considered as a revolution against eastern philosophy. He believes the epistemological gap between these two fields (Jaberi, 2012: 13).To prove such a claim, Jaberi proposes many reasons among which social and cultural conditions and factors in the west in the era of Movahedin and Cultural Revolution of that era is among the most important ones. Jaberi states that it is true which Baghdad in the east was considered the main center of Islamic-Arabic culture and had a long record compared to Cordoba and Fès and even it contributed to other centers of rational and theological narrative sciences in such a way that under the disguise of such contributions these thoughts were spread, which all writings of the west were the repetitions of the east and even one of the eastern scholars when was studying one of the writings of the west stated that "these are our works which have been returned to us", but these claims and statements were true before the era of Movahedin government.

The reform movement of IbnTumart transformed the conditions totally. The movement made by IbnTumart was changed rapidly into a cultural revolution whose motto was to leave imitating the easterners and returning to genuine principles and culture of Islam. The revolution which was started by IbnTumart and competed by Averroes and his disciples. On the other hand, because of various ethnicities and cultures in the east, this part of Islamic world suffers from a socio-political gap and its philosophers pursue the agreement between religion and philosophy in order to create a theoretical unity and under its light, brings a social and political unity and the unity of the society and government. This statement means that the philosophers of the east of Islamic world primarily were to change philosophy to an ethnic and religious ideology. Dr. Jaberi accepts this meaning and attempts to prove this meaning. According to this Moroccan scholar, the principle of this issue is reinforced in Farabi and culminates in Avicenna, while philosophers in the west do not need to merge philosophy into religion and are free from these intellectual challenges (ibid:11).

To Jaberi, the epistemological difference and gap of Averroes and Avicenna mean that Averroes pondered regarding a problem other than the problem of Avicenna. In his view, Averroes practiced more advanced than Avicenna in the common field and in the same culture which both tended toward. Therefore, according to this Arab scholar: "the Arabic-Islamic philosophy in the east was heavenly because of being drowned in the issue of compromising between philosophy and religion in terms of epistemology and the type of approach, while in the philosophy of the west, the scientific secular and epistemological approaches were dominated because of such problems (Jaberi, 2008: 18).

Dr. Jaberi regularly refers to this gap and writes:

\begin{abstract}
"The reality is that objective and futurist rationalism of Averroes cannot be considered to be related by no means to the grace-centered metaphysics of Avicenna and Farabi since Averroes was the peak of cultural revolution which the reform movement of IbnTumart created" (Jaberi, 2010: 138).
\end{abstract}

According to this former professor of the University of Rabat, the basic concepts on which the intellectual structure of the east is constructed in Abbasid Era are as follows: the creation of the world, possibility and necessity, Divine and human knowledge,diversity and unity, ...; therefore, the issue refers to a dichotomous set of contradictory concepts which are related to each other... the theoretical thought of the east whether in theology or in philosophy attempted to create these dichotomous concepts. Like the attempt to compromise between reason and narration (topologists) and religion and philosophy (Farabi and Avicenna) and all these are the foundations of a new construction which satisfy reason and narration. Therefore, when one states that Averroes does not accept these concepts means that Averroes does not 
accept the theme or themes which western philosophers create from these concepts because they create themes to these concepts in their framework which is based on the three-valued logics (ibid, 2012: 86). He states his objective of proposing this epistemological difference and gap in the field of east and west as a tool which gives us the possibility to understand more comprehensively and intimate the internal dynamism of our own ancestors. Without such understanding and relation, our legacy as has been up to now, will be a legacy which burdens us and prevents us from improving (ibid, 2012: 80). He believes that Averroes looks at the theoretical thought in the east as a unit thought which unity in method constructs it and he rejects this method because he believes that it is non-discursive. Not to accept this method by Averroes shows that he pursues a discursive one which is greatly different from eastern method (ibid: 81).

\section{The ideas of Professor Henry Corbin}

Henry Corbin, the famous French orientalist believes in the gap and difference between the east and the west. He considers the names of Avicenna and Averroes as codes of spiritual appreciation which is waiting for the east and the west (Corbin, 1994: 350).

Corbin basically takes Islamic philosophy in the meaning of "Prophetic Theosophy" which cannot explain it without discussing mysticism including Sufism as aspiritual experience and theoretical wisdom having root in esoteric teachings the Shia Imams (Corbin, 1994: 5). Therefore, according to Corbin, the history of philosophy in Islam is not particularly separable from the history of spirituality. In other words, the existence of spiritual Islam is dependent on this keeping interiority; otherwise, Islam underwent the same process which in Christianity changed the theological systems into social ideologies and theological limitations as a social limitation and normative issue (ibid: 15).

The foundation of metaphysics of spirituality which Corbin pursues is based on this principle that heavens and all universe are not only esoteric, but also in real terms full of spiritual presence. This spiritual presence shapes the divine world or Noland of Suhrawardi. There is called Noland in this sense that its place is not similar to the materialistic world of us, but it has a special place of its own and in this sense it is not pure nothingness and divestment. This place has its own residents and the suffix "land" added to originates from it. Among the residents of this Noland are constellational population. In fact, constellational population are angels and heavenly creatures in a rank lower than the Favored Angels (intellects). They move heavens and by moving heavens, they are organizers of our world. Belief in constellational population is the origin and basis of belief in "Noland" and in general spiritual worlds and presences.

Therefore, after translating Avicenna's books into Latin, this theory encountered opposition and invective and ridicule of the official church; and indeed such a reaction was not expectable because the church could not accept no intermediate party between humanity and God; therefore, found constellational population as a rival to itself against which should be stood and it should be removed. This is why Corbin consider Copernican revolution to be based on theological revolution. Firstly the Christian theologians was that removed spiritual presence from the world. To them, no intermediate party should stand between God and humanity. Therefore, not only did they remove constellational population, but they also limited the influence realm of intellects. "Something which troubled official theology was basically all the theory of intellects and its result, i.e. active reason as the illumination of the human population- briefly all of angelology. Theology should fight with any grace-centered theory, consider the creative act as only the conclusive right of God and end the monologue of human's soul with active reason (Corbin, 2008: 219). However, this official theology with over emphasis on free will (absolute power) of God, to explain the relationship of God with the world in general and God and humanity in particular, did not consider for itself any logics and rational ground and basically rejected the existence any intermediation such as creatures and spiritual presences in the name of polytheism and limitation of God's power. After that the world of angels is considered as a kind of luxury in the creation (ibid). Accordingly, there was no place for spiritual journey in the sense of ascension of humans to the super worlds. Heavens were considered as mundane and without any angel. Therefore, between the earth and other planets, there was no difference; humanity can only has a relation of identical and homogenous thralldom with God. And for this, an institution is required to regularize the principles of this relationship. This is the reason why Corbin believes that the separation of theology and philosophy which returns to Latin scholastic theology is the first sign of "metaphysical secularization" and its result is belief in the dichotomy of science and faithfulness and finally "dichotomous truth" which is not basically from Averroes, at least is attributed to some of the followers of Averroes. The reason of this issue is that Averroes separates himself from Prophetic Theosophy (Corbin, 1994: 17).

According to Corbin, this is the reason why Averroes's school was eliminated in itself and also for a very long time, it has been considered as the theology of Islamic philosophy, while this school has not been more than a stalemate, a period when has been removed from the mind of eastern philosophy (ibid). According to Corbin, a scientific and precise comparison has not been conducted. Such a comparison can clarify not only the basic trends but also the results of 
Averroes's ideology form this perspective that this ideology resulted in elimination of Avicenna's second angelology, i.e. angles or heaven population. In fact, this world of heavenly population in such a way that illumination tradition emphasizes it, the same world is an independent forms which can be understood through creative imagination. This is the same world where prophets and mystic views and also the meaning of Doomsday and plurality of meanings of revelation in which every meaning is the code of another meaning are met. By removing this intermediate world, how will be the birth and rise of soul?

Because Averroes tended to revive Aristotle's ideology, he criticized the three designs of Avicenna who brought between pure intellects and heavens the heavenly population. According to Averroes, the motivation of any heaven is a finite characteristics and force which achieve a finite force by an enthusiasm that moves it toward a creature which neither body nor force of the body but is a pure reason which moves this enthusiasm as the final reason. According to Averroes, in terms of nominal commonality, this motivating force and this enthusiasm which is pure reason can be called the Soul (ibid: 348 ).

In Corbin's view, the main motivation of this severe criticism is the basic position against the theory of Grace proposed by Avicenna and successive emission of intellects from a single issue because there is an issue which links the concept of emission with the thought of creation and thought of creation is understandable for a pure Peripatetic philosopher.

Corbin summarizes the effects of lack of attention to the World of Idea or Heaven which originate from Averroes as follows:

1. Hereinafter, there will be no sympathetic meet between a philosopher and the prophet in the intermediary world.

2. The world of Intellects which tends to pure rationality and the world of experiential data, without intermediation and relationship which can be able to change one into another, will be stand against each other.

3. In this approach, because of eliminating the spiritual intermediary world, text and appearance of the religion will be the base.

4. And, the world which its higher rank i.e. the heavenly population are fragmented will be felt in the rank of human population and anthropology. Here, the conflict between Avicenna's school and that of Averroes will be apparent because this conflict influences the basic concept of epistemology and anthropology i.e. the concept of active reason; therefore, the relationship between human soul and this reason requires investigation. Accordingly, the separation between the faithfulness and rational knowledge and also the separation between the existence and thought have pervaded the western thoughts for many centuries, while Iranian philosophical traditions, Avicenna and Illumination, were totally dismissed of this separation. On the other hand, Averroes's school takes the responsibility of the theory of dichotomous truth and the coexistence of two contradictory truths, even if Averroes himself did not want so. This coexistence is dangerously unstable (Corbin, 1990: 123 onwards).

This is why from the viewpoint of Corbin, Averroes belongs to the western destiny of philosophy and has no place in eastern one. Averroes opposed to any emission or grace because the idea of emission is a kind of belief in the creation of universe from nothingness and according to Aristotle, such a creation is unacceptable. With this introduction, the Avicenna's principle of "Al-Vahid" becomes without foundation; therefore, the causal system founded on this principle is undermined.

Corbin's approach is totally different from what Dr. Jaberi presents. He primarily pays attention to Avicenna and also considers him as the head of philosophical thought in Islamic world, while Dr. Jaberi contrary to this idea, believes that Avicenna not only is the representative of dynamicity and flourishing philosophical thought, but also it should be considered as the peak of the rigor and decline in Islamic culture. Jaberi takes the salvation and freedom from the recession and the cultural and intellectual rigor as paying attention to genuine and reason-based thoughts of Averroes and takes as important the kind of his approach to philosophy and religion. The point which both scholars emphasize is that between philosophical thought in the east and west of Islamic world, there is a great difference and never can take one the continuance of the other.

\section{Conclusion}

The cultural difference between the west and east of Islamic world is not only among the schools between which there is no proximity, but also has penetrated in Islamic world and has separated two great peripatetic philosophers. It seems that the kind of Averroes's approach to Islamic discussions and also his interpretation of Aristotle are the most effective factors in to create a separation between the thoughts of philosophers like Avicenna. Although Avicenna did not start to 
independently write regarding the agreement between philosophy and religion, his approach was in line with the agreement and in some cases which this agreement resulted lack of association of reason with religion, he immediately renounced rational approach by announcing religious position. This issue is highly important in the issue of bodily resurrection, while Averroes in line with agreement between philosophy and religion writes an independent work, in case which basically the issue of agreement between philosophy and religion has not been in the cultural and intellectual atmosphere of Murabetin Era (Jaberi, 1993: 26).Accordingly, mostly, his work is not only the agreement between philosophy and religion, but also is an attempt to determine the limitation of these two intellectual concepts and also identify the certain domains of each concept. This view is related to a book which Averroes published in this line. The book "Fasl-o-al-Maghal" speaks of the end of conflicts and not merging one into another.

Accordingly, based on the kind of Averroes's approach to religious and philosophical discussion, it seems that the content of his philosophy is different from what Avicenna was to present and mainly have been presented in religious form and shape. Therefore, if the title "Islamic philosophy" can be considered as one of the important approaches during the history of philosophical thoughts, undoubtedly Avicenna can be taken as its head, while according to a port presented by Gilson, Averroes did not agree with this interpretation and was to present a different approach (Gilson, 1996: 135).

Therefore, although the distance and inaccessibility to the works of a philosopher like Averroes which is the only representative of defending philosophical thought in Islamic world and it has been effective in his ideas and views in the east, one cannot speak of it as the only effective factor because nowadays called the age of information, the lack of accessibility to these works has not geographical and scientific justifiability and it seems that unwillingness to schools of the east informs us his thought from a different approach to religious and philosophical discussions; and approach which is different from objectives and concerns of professors in the east at least in the content and promises a new outcome. The outcome which in its nature promises the separation of religion and philosophy and this issue undoubtedly is unacceptable for eastern schools and do not welcome it as a secularist approach.

\section{Resources}

Abed Al-Jaberi, M. (2008). We and our philosophical legacy. S.M. Al Mahdi (Trans.). Tehran: Sales publication. (2012). A new reading of western philosophy. S.M. al Mahdi (Trans.). Tehran: Sales publication.

(1994). Contemporary Arabic teachings, analytical and critical teachings. Beirut. Center of Arabic teachings.

.............. (1991). Al-Torath and Al-Hedatha, teachings and conflicts. Beirut: center of Arabic teachings.

(1993). We and Al-Torath. Beirut. Center of Al-thaghafi Al-Arabi.

(1991). Averroes, Arabic thinker. Cairo: Center of Al-Saghafah.

Adamson‘Peter\&Taylor،C.Richard (2005). The Cambridge companion to Arabic philosophy.Cambridge university press.

Atef Al-Araqi, M. (2002). Averroes, Arabic philosopher in the west. Cairo: center of Al-Saghafa.

Ashtiani, J. (1999). A criticism of Tahof-Al-falasafa of Gazali. Qom: BustanKetab publication.

Al-Shirazi, S. (1981). Transcendent theosophy in writings of quad reasons. Vol. 8. Beirut. Dar-Al- Ehya Al- Torath A-Arabi.

Al-Helo, A. (1960). Averroes, the philosophers of the West. Beirut: Dar-ol-Sharq Al-Jadid.

Averroes, A. (1998). Al-tahafot Al-tahafot. Vol.2. Cairo. Encyclopedia. Soleiman Al-Donya.

Corbin, H. (1994). History of Islamic philosophy. J. Tabatabaiei (Trans.). Tehran: Kavir publication.

(2008). Avicenna and mystic symbolism. E. Rahmati (trnas.). Tehran: Jami publication.

(1990). Iranian philosophy and comparative philosophy. J. Tabatabaei (Trans.). Tehran: Toos.

Davari, R. (2010). We and the history of Islamic philosophy. Tehran: Book Publication.

.. (2002). Averroes, Islamic philosopher, foundation of renaissance and teacher of modernization of the west of Iran. Journal of

Philosophy. No. 6 and 7.

Davidson،Herbert (1992). Alfarabi،Avicenna،and Averroes on intellect. Oxford University press.

De Beur. T.J. (1983). History of philosophy in Islam. A. Shoghi (Trans.). Tehran: Ataei publication. $3^{\text {rd }}$ edition.

Durant, W. (1987). History of civilization. Vol. 4. A. Payandeh et al. (Trans.). Tehran: Publication organization. $2^{\text {nd }}$ edition.

EbrahimiDinani, Gh. (2000). The story of philosophical thinking in Islam. Tehran: Tarhe No publication.

(2005). Averroes shine in the peripatetic philosophy. Tehran: Tarhe no publication.

Fakhri, M. (1993). Development of philosophy in Islamic world. N. Pourjavadi (Trans.). vol. 3. Tehran: NashrDaneshgahi.

Gilson, E. (1996). Introduction to Christian philosophy. M. Mohammad Rezaei\& S.M. Mousavi (Trans.). Qom: Islamic Propagation.

Herald،stone (1996) Why Europeans stopped reading Averroes.Journal of comparative poetics.no.16.

Leman, O. (2004). History of Islamic philosophy. S.H. Nasr (Trans.). Tehran: Hekmat publication.

Nasr, H. (2006). In search of the sacred. M. Shahraeini (Trans.). Tehran: Nei publication.

Renan, E. (1957). Averroes and Al-Rushdia. A. Zaitra. (Trans.). Cairo. Dar-Al-Arabia.

Russell, B. (1994). Western history of philosophy. N. Daryabandari (Trans.). Tehran: Parvaz.

Sharif, M.M. (1983).hsitroy of philosophy in islam. Vol 1. Tehran: Nashrdaneshgahi. 